\title{
EFFECT OF MANGANESE CONTENT ON THE IMPACT TOUGHNESS AND CORROSION RESISTANCE OF DEPOSITED METALS OF WEATHERING STEEL
}

\author{
VPLIV VSEBNOSTI MANGANA V ELEKTRODAH ZA \\ NAVARJANJE NA KOROZIJSKO ODPORNOST IN UDARNO \\ ŽILAVOST KOROZIJSKO OBSTOJNEGA JEKLA
}

\author{
Xiao Zhuo ${ }^{1,2 *}$, Tongbang $\mathrm{An}^{2}$, Chengyong $\mathrm{Ma}^{2}$, Lixin $\mathrm{Li}^{1}$ \\ ${ }^{1}$ Hebei University of Science \& Technology, 050018 Hebei, China \\ ${ }^{2}$ Central Iron and Steel Research Institute, 100089 Beijing, China \\ Prejem rokopisa - received: 2019-05-17; sprejem za objavo - accepted for publication: 2019-11-08
}

doi:10.17222/mit. 2019.108

\begin{abstract}
In this study the Mn content fluctuations in the deposited metals and their influence on the impact toughness and corrosion resistance were investigated. The experimental results indicated that the deposited metal containing 1.05 w/\% Mn when compared with the deposited metal containing $1.34 \mathrm{w} / \% \mathrm{Mn}$ increased the impact toughness by $40 \%$ and that the increment in energy absorbed by the crack propagation accounted for $88 \%$ of the increment in impact energy. Further, the self-corrosion potential difference between the deposited metals and the weathering steel was less than $20 \mathrm{mV}$, leading to similar corrosion resistances. The results revealed that the Mn content fluctuations did not significantly influence the self-corrosion potential of the deposited metals; furthermore, the increase in the impact toughness can be attributed to: a) the decrease in the volume fraction of the grain-boundary ferrite and ferrite side plates in the columnar zone, b) an increase in the number of large grain boundaries in the fine-grain reheating zone, and c) the refining of the martensite-austenite constituents.

Keywords: multipass welding, impact toughness, self-corrosion potential
\end{abstract}

V članku avtorji opisujejo študijo, v kateri so raziskovali vpliv spremembe vsebnosti mangana v elektrodah za navarjanje in njen vpliv na udarno žilavost in odpornost proti koroziji. Eksperimentalni rezultati kažejo, da se je udarna žilavost korozijsko odpornega jekla povečala za $40 \%$ in je bil prirastek udarne energije $88 \%$, ko je bilo jeklo varjeno z elektrodo, ki je vsebovala 1,05 mas. \% Mn, v primerjavi s tisto, ki je vsebovala 1, 34 mas. \% Mn. Nadalje so ugotovili, da je bila razlika med samo-korozijskima potencialoma navarjene plasti in jekla manjša kot $20 \mathrm{mV}$ pri podobni odpornosti proti koroziji. Rezultati raziskave kažejo, da spremembe vsebnosti mangana niso pomembno vplivale na samo-korozijski potencial navarjene plasti. Nadalje avtorji še ugotavljajo, da lahko pripišemo povečanje udarne žilavosti: a) zmanjšanju volumskega deleža ferita na mejah med zrni in ferita na bokih plošč v stebričasti coni, b) povečanju deleža velikih kristalnih mej v fino zrnati coni pregretja in c) udrobljenju martenzitno-austenitnih komponent.

Ključne besede: varjenje v več korakih, udarna žilavost, samo-korozijski potencial

\section{INTRODUCTION}

Weathering steel (WS) is a class of low-alloy steel that can form a layer of rust to resist atmospheric corrosion. With the development of bridges using weathering steel, satisfactory toughness and good corrosion resistance are important requirements from the new generation of WSs. Recently, a new kind of ultra-low carbon thermo mechanical control process (TMCP) WS with considerable corrosion resistance and impact toughness was developed. This kind of WS will be extensively used because of its excellent properties (i.e., high strength, toughness, and corrosion resistance). ${ }^{1-5}$ It can also be used as structural steel for railways, vehicles, bridges, and towers and can withstand long-term atmospheric exposure. ${ }^{6}$ In the future, an increasing amount of WS will be used in low-temperature environments (below the scope of the usual test temperature of the

*Corresponding author's e-mail:

kdzhuoxiao@163.com (Xiao Zhuo) weather-resistant welding material, i.e., below $-5{ }^{\circ} \mathrm{C}$ ). Thus, there is a requirement for appropriate welding consumables in the case of such materials. Matching impact toughness and corrosion resistance is the requirement to ensure suitable properties of the WS welded joints.

In engineering applications, the process of multilayer and multipass welding is essential to achieve a complex structure. ${ }^{7}$ However, this process divides the deposited metals into several zones (columnar crystal zone, coarse-grained reheated zone, and fine-grained reheated zone), complicating the microstructure and making it difficult to distinguish and study. ${ }^{8}$ Further, the mechanical properties of the welding consumables are usually classified by testing the samples of the deposited metals, which are typically subjected to multipass welding. A comprehensive analysis of the microstructural changes in all the regions is necessary to identify the causes of the changes in impact toughness and corrosion resistance. 
X. ZHUO et al.: EFFECT OF MANGANESE CONTENT ON THE IMPACT TOUGHNESS ...

Table 1: Welding parameters used in this study

\begin{tabular}{|c|c|c|c|c|c|c|}
\hline Number of layers & Number of passes & $\begin{array}{c}\text { Interpass temper- } \\
\text { ature }\left({ }^{\circ} \mathrm{C}\right)\end{array}$ & $\begin{array}{c}\text { Current } \\
(\mathrm{A})\end{array}$ & $\begin{array}{c}\text { Voltage } \\
(\mathrm{V})\end{array}$ & $\begin{array}{c}\text { Welding speed } \\
(\mathrm{mm} / \mathrm{s})\end{array}$ & $\begin{array}{c}\text { Heat input } \\
(\mathrm{kJ} / \mathrm{mm})\end{array}$ \\
\hline 6 & 18 & 100 & 165 & 26 & 2.8 \\
\hline
\end{tabular}

Table 2: Chemical compositions of the deposited metals with respect to the studied specimens $(w / \%)$

\begin{tabular}{|c|c|c|c|c|c|c|c|c|c|c|c|}
\hline & C & $\mathrm{Si}$ & $\mathrm{Mn}$ & $\mathrm{S}$ & $\mathrm{P}$ & $\mathrm{Cr}$ & $\mathrm{Ni}$ & $\mathrm{Cu}$ & $\mathrm{Ti}$ & $\mathrm{B}$ & $\mathrm{Fe}$ \\
\hline No.1 & 0.033 & 0.34 & 1.05 & 0.0022 & 0.0067 & 0.23 & 1.15 & 0.32 & 0.035 & 0.0027 & $\mathrm{Balance}$ \\
\hline No.2 & 0.034 & 0.32 & 1.34 & 0.0021 & 0.0078 & 0.24 & 1.14 & 0.3 & 0.035 & 0.0028 & Balance \\
\hline
\end{tabular}

Recent research on the welding consumables for WS, mainly in $\mathrm{Cr}$, $\mathrm{Ni}$, and $\mathrm{Cu}$, elements that have a sensitive influence on the material's corrosion resistance. ${ }^{9-12}$ In reality, ensuring the corrosion resistance and suitable mechanical properties of the weld becomes a difficult task. This study considers the concept of coordinating the impact toughness with suitable corrosion resistance. Further, this study intends to investigate the influence of $\mathrm{Mn}$ on the impact toughness and corrosion resistance of the deposited metals.

\section{EXPERIMENTAL PART}

Two weathering electrodes were designed with different Mn contents. The unified welding parameters adopted in the study are presented in Table 1. The weld-deposition sequence is presented in Figure 1. No evidence of weld cracking could be observed after welding. Further, the chemical compositions of the two deposited metals are presented in Table 2. The values for each element were almost uniform, except for $\mathrm{Mn}$ (1.05 w/\% and $1.34 w / \%)$. The observed variations in values among the different specimens were within the accepted range in the case of this determination. Furthermore, the chemical compositions of WS include C: 0.058, Si: 0.28, Mn: 1.44, S: 0.001, P: 0.008, Cr: 0.48, Ni: 0.32, Cu: 0.31, Mo: 0.15, Ti: 0.015, B: 0.0002, Nb: 0.035, V: 0.065, and Fe: balance.

The Charpy impact test was performed using an American Tinius Olsen Pendulum tester having a capacity of $750 \mathrm{~J}$ at $-40{ }^{\circ} \mathrm{C}$. Five impact samples were tested to avoid any errors, and the average values were calculated. The specimens were mechanically polished using standard metallographic procedures and etched

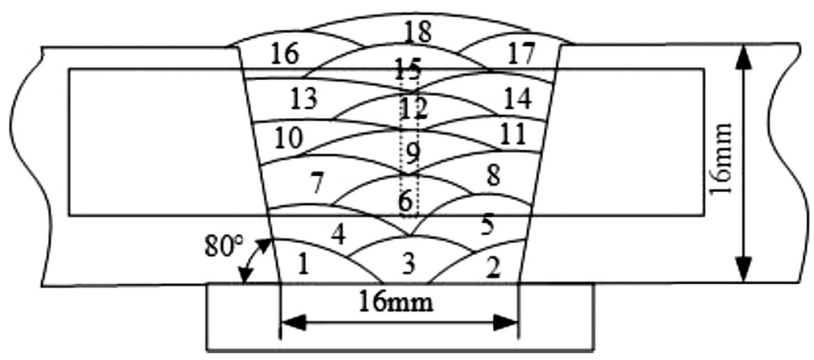

Figure 1: Details of the dimensions and sequence of multipass welding with $4 \%$ nital before performing the microstructural examination on an Olympus GX51 optical microscope. Further, the investigated columnar and reheated zones were distributed along the vertical central line in the case of the Charpy impact test location.

Subsequently, the electrochemical measurements were performed using a standard three-electrode system on a PAR 273A electrochemical workstation. A platinum plate and a saturated calomel electrode (SCE) were obtained as the auxiliary electrode and the reference electrode, respectively, and the deposited metal specimen with an exposed area of $1 \mathrm{~cm}^{2}$ was used as the working electrode. All the electrochemical experiments were conducted in a corrosive electrolyte containing $2.0 \mathrm{w} / \%$ $\mathrm{NaCl}$, prepared to simulate marine atmospheric corrosion.

An FEI Quanta650 FEG equipped with an EBSD detector (Oxford Nordlys F+) was utilized to collect the electron back-scattered diffraction (EBSD) scans from the identified microstructural regions. The acceleration voltage of the electron beam in the case of the EBSD measurements was $17 \mathrm{kV}$, and the ion-beam current was $342 \mu \mathrm{A}$. The step size was $0.5 \mu$ Further, a macroscopic impact fracture was observed using a scanning electron microscope. The Lepera etchant (a solution of $1 \mathrm{~g}$ sodium metabisulfite in $100 \mathrm{ml}$ water mixed with $4 \mathrm{~g}$ of picric acid dissolved in $100 \mathrm{ml}$ of water) was used to reveal the martensite-austenite (M-A) constituents. The statistical results of the grain-boundary ferrite (GBF) and ferrite side plate (FSP) in the columnar region are the average values obtained from ten visual fields.

\section{RESULT AND DISSCUSSION}

\subsection{Effect of Mn on the corrosion resistance of the deposited metals}

The electrochemical parameters of the deposited metals and WS were obtained by Tafel fitting of the potentiodynamic polarization curves (Figure 2). The specimens containing $1.05 \mathrm{w} / \%$ and $1.34 \mathrm{w} / \% \mathrm{Mn}$ exhibited self-corrosion potentials of $0.474 \mathrm{~V}$ and $0.477 \mathrm{~V}$, respectively, in an electrolyte containing $2 w / \% \mathrm{NaCl}$. The self-corrosion potential of WS was $0.459 \mathrm{~V}$ (vs. SCE) and exhibited negligible fluctuation. X. M. Xiao et al. ${ }^{9}$ observed that alloy elements are the main factors that determine the longtime corrosion behavior of the 


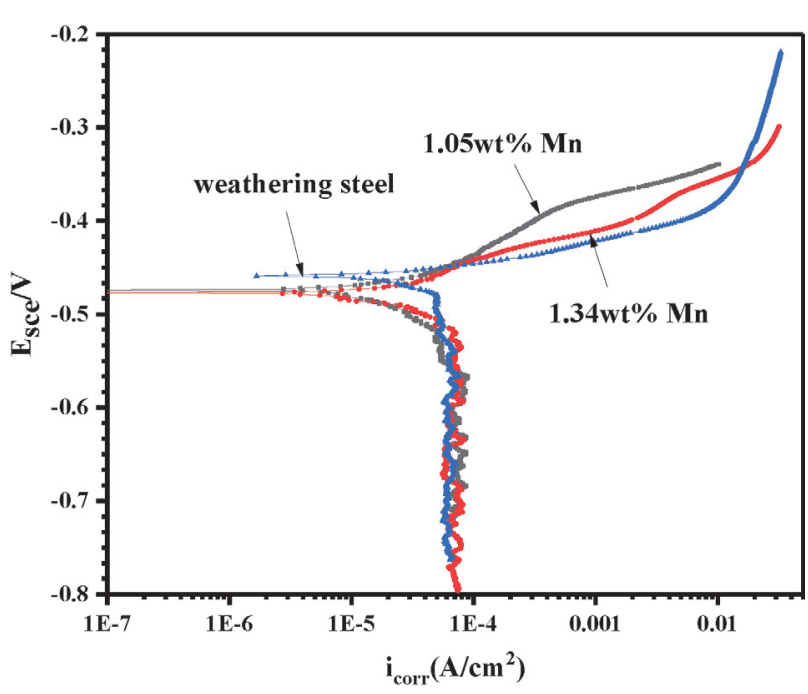

Figure 2: Polarization cures of weathering steel and deposited metals in an electrolyte containing $2 \mathrm{w} / \% \mathrm{NaCl}$

deposited metal and that the microstructure affects only the initial corrosion behavior. This indicated the existence of no significant differences among the self-corrosion potentials of two specimens. Further, Ecorr did not exhibit a significant change with the changing Mn content in the deposited metals. Subsequently, the self-corrosion potential difference between the deposited metals and the WS is less than $20 \mathrm{mV}$, realizing the matching of the corrosion resistance. This phenomenon can be used to design the mechanical properties of the welding consumables after the corrosion resistance of the deposited metals is satisfied.

\subsection{Effect of Mn on the microstructure of the depo- sited metals}

Table 3 presents the mechanical properties of the deposited metals. When compared with that of deposited metals containing $1.34 \mathrm{w} / \% \mathrm{Mn}$, the low-temperature impact toughness of the specimens with a lower Mn content $(1.05 \%)$ increased by $40 \%$, and the elongation and the reduction of the area contraction ratio did not change significantly. Furthermore, the strength was reduced by $30 \mathrm{MPa}$.

Table 3: Mechanical properties of the deposited metals

\begin{tabular}{|c|c|c|c|c|c|}
\hline & $\begin{array}{c}\text { Tensile } \\
\text { strength } \\
(\mathrm{MPa})\end{array}$ & $\begin{array}{c}\text { Yield } \\
\text { strength } \\
(\mathrm{MPa})\end{array}$ & $\begin{array}{c}\text { Tensile } \\
\text { elongat- } \\
\text { ion }(\%)\end{array}$ & $\begin{array}{c}\text { Area } \\
\text { contrac- } \\
\text { tion ratio } \\
(\%)\end{array}$ & $\begin{array}{c}\text { Impact } \\
\text { test } \\
\text { energy at } \\
-40^{\circ} \mathrm{C}(\mathrm{J})\end{array}$ \\
\hline No.1 & 605 & 529 & 29.0 & 76.5 & 189 \\
\hline No.2 & 639 & 563 & 27.5 & 75.5 & 135 \\
\hline
\end{tabular}

The sum of the crack-initiation-absorbed energy and the crack-propagation-absorbed energy can be used to evaluate the impact toughness. ${ }^{13}$ Figure 3 depicts the typical curves of the impact load-deflection for two kinds of electrodes corresponding to different Mn con-

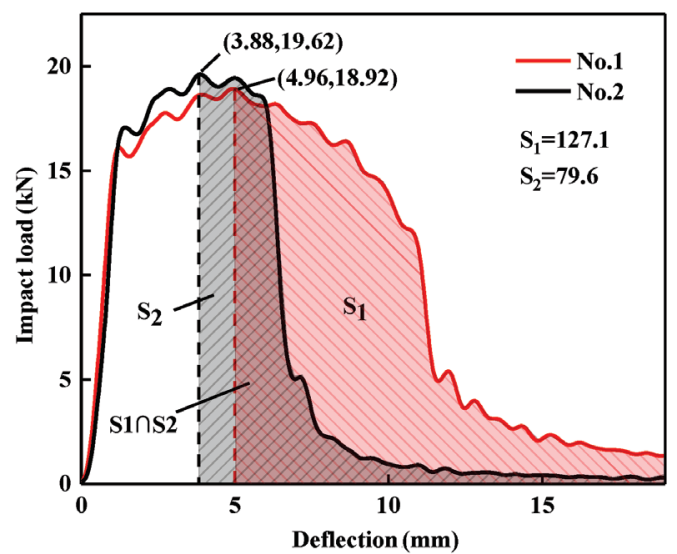

Figure 3: The load and deflection curves of the deposited metals

tents. The integral results under the load-deflection curves indicated that the crack-initiation-absorbed energy of the No. 1 specimen increased by $6.346 \mathrm{~J}$, whereas the crack-propagation-absorbed energy increased by $47.49 \mathrm{~J}$. The ratio of the crack-propagationabsorbed energy to the impact toughness also increased by $8 \%$.

The macroscopic fracture is depicted in Figure 4. As can be observed, the length of the No. 1 ductile propagation zone is significantly greater than that of the No. 2 zone. As denoted by the load-deflection curves, there was a considerable difference in the crack-propagationabsorbed energy between the two groups of specimens
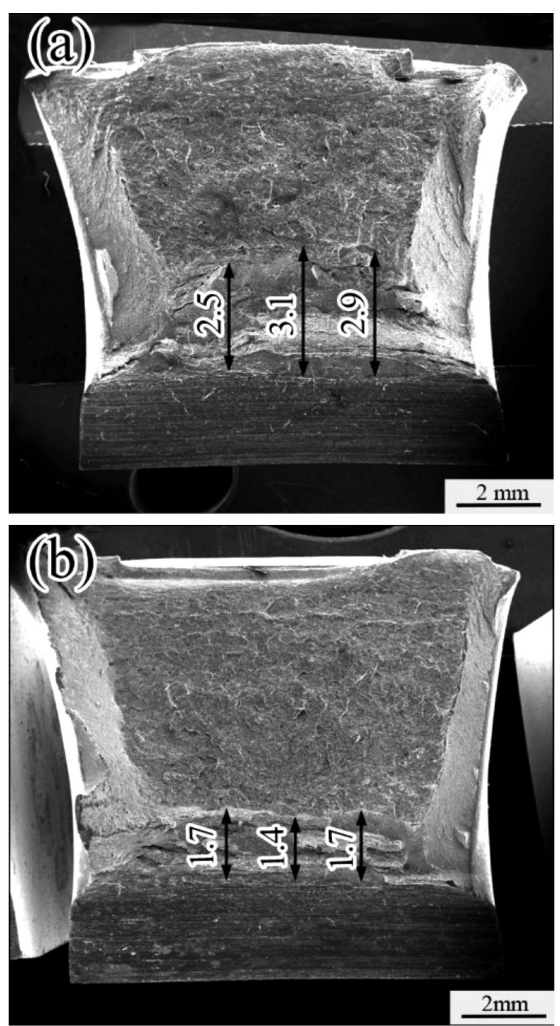

Figure 4: Macroscopic fractures of the impact specimens: a) No. 1, b) No. 2 
because of the considerable load at this stage. The change in crack-initiation-absorbed energy indicates that the Mn exhibiting low-temperature impact toughness influenced the crack propagation. The Mn content change of the deposited metals on the impact toughness in the case of WS influenced the crack-propagationabsorbed energy.

Because of the thermal reheating cycles, the microstructures of the multipass welding specimens comprised not only the as-deposited weld metal but also two mainly reheated zones. Each reheated zone can be referred to as the fine-grained reheated zone (FGRZ) and the coarsegrained reheated zone (CGRZ). ${ }^{7}$ Figure 5 denotes a typical microstructure distribution. The volume fractions of the columnar and reheated regions at the Charpy V-notch sample location are presented in Table 4. As can be observed, the impact specimens mainly comprised FGRZ, whereas the volume fraction of each region of the specimen exhibited little difference.

Table 4: Volume fraction of the columnar and reheated regions

\begin{tabular}{|c|c|c|c|}
\hline & $\begin{array}{c}\text { Columnar } \\
\text { regions (\%) }\end{array}$ & $\begin{array}{c}\text { Coarse-grained } \\
\text { reheat regions } \\
(\%)\end{array}$ & $\begin{array}{c}\text { Fine-grained } \\
\text { reheated } \\
\text { regions (\%) }\end{array}$ \\
\hline No.1 & 18 & 5 & 77 \\
\hline No.2 & 17 & 4 & 79 \\
\hline
\end{tabular}

The typical microstructure of the columnar zone is presented in Figure 5a and 5d. With an increase in Mn content, a progressive refinement of the microstructure can be observed. The average width of the columnar grains decreased with increasing $\mathrm{Mn}$. This phenomenon was also observed and reported in a previous study. ${ }^{14}$ With respect to the microstructure, GBF and FSP were distributed in the grain boundary of the columnar grain, and fine acicular ferrite (AF) was distributed in the grain, as depicted in Figure 5. The GBF and FSP volume fractions account for $8.3 \%$ in the columnar zones of the $1.05 w / \% \mathrm{Mn}$ specimens, whereas they account for $11.4 \%$ in the case of the 1.34 w/\% Mn specimens columnar zones. By comparing the microstructure proportions, we can observe that the No. 2 specimen exhibited larger FSP and GBF volume fractions when compared with those exhibited by the No. 1 specimen. GBF and FSP exhibited brittle phases or a high dislocation density, which was unfavorable for achieving impact toughness. The difference in the microstructure proportion can be explained by the influence of $\mathrm{Mn}$ on the thermodynamic conditions. ${ }^{15-17}$

$\mathrm{AF}$ is one of the optimum microstructures for the 500-600-MPa grade weld metal. It has a very fine grain size, and several large-grain boundaries are responsible for its toughness. ${ }^{18}$ The crystal morphologies of AF in the columnar zones were obtained by EBSD. As presented in Tables 5 and $\mathbf{6}$ and Figure 6, the AF in the columnar zone does not significantly change with increasing Mn content, which can be explained by the relation between $\mathrm{AF}$ and inclusions containing Ti. The fine $\mathrm{AF}$ structure originates from the heterogeneous nucleation of ferrite plates in the case of nonmetallic inclusions within the austenite grains, as demonstrated. ${ }^{19,20}$

Table 5: Effective grain size information of the regional microstructure

\begin{tabular}{|c|c|c|c|}
\hline & Columnar zone & CGRZ & FGRZ \\
\hline No.1 & $2.63 \mu \mathrm{m}$ & $2.25 \mu \mathrm{m}$ & $2.97 \mu \mathrm{m}$ \\
\hline No.2 & $2.48 \mu \mathrm{m}$ & $2.31 \mu \mathrm{m}$ & $3.1 \mu \mathrm{m}$ \\
\hline
\end{tabular}
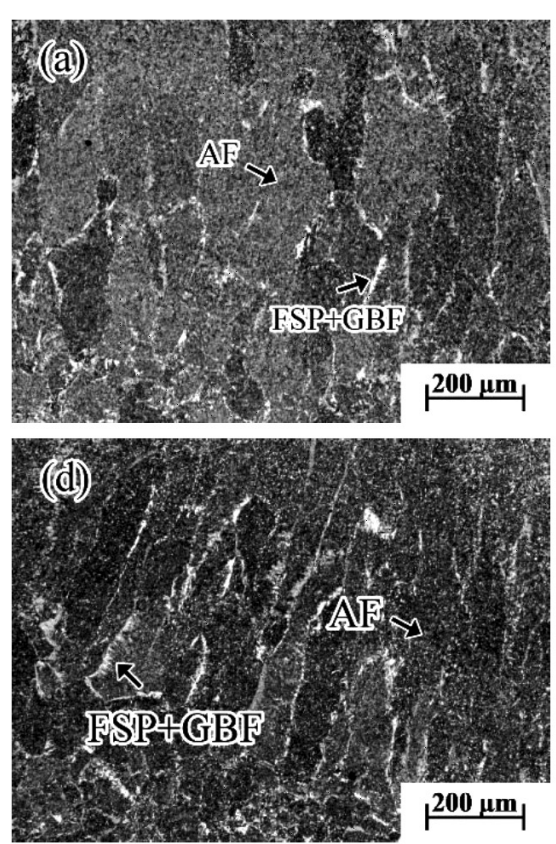
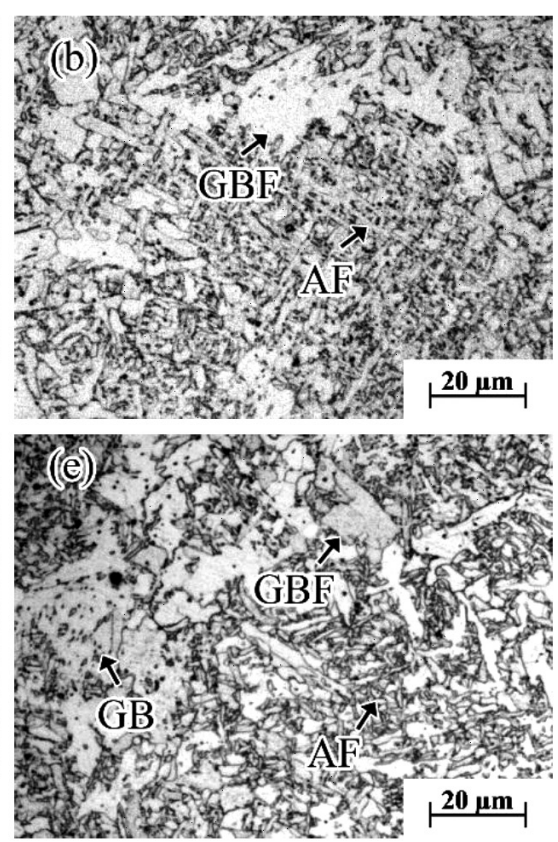
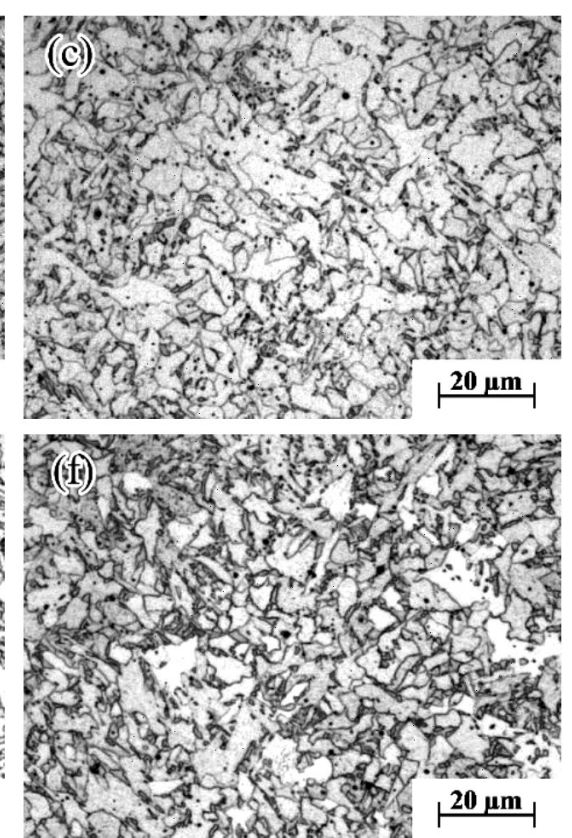

Figure 5: Microstructure of the columnar zone and reheated zone: a) to c) are columnar zone, GCRZ, FGRZ metallography specimen containing $1.05 \mathrm{w} / \% \mathrm{Mn}$ and d) to f) are columnar zone; GCRZ, FGRZ metallography specimen containing $1.34 \mathrm{w} / \% \mathrm{Mn}$ 


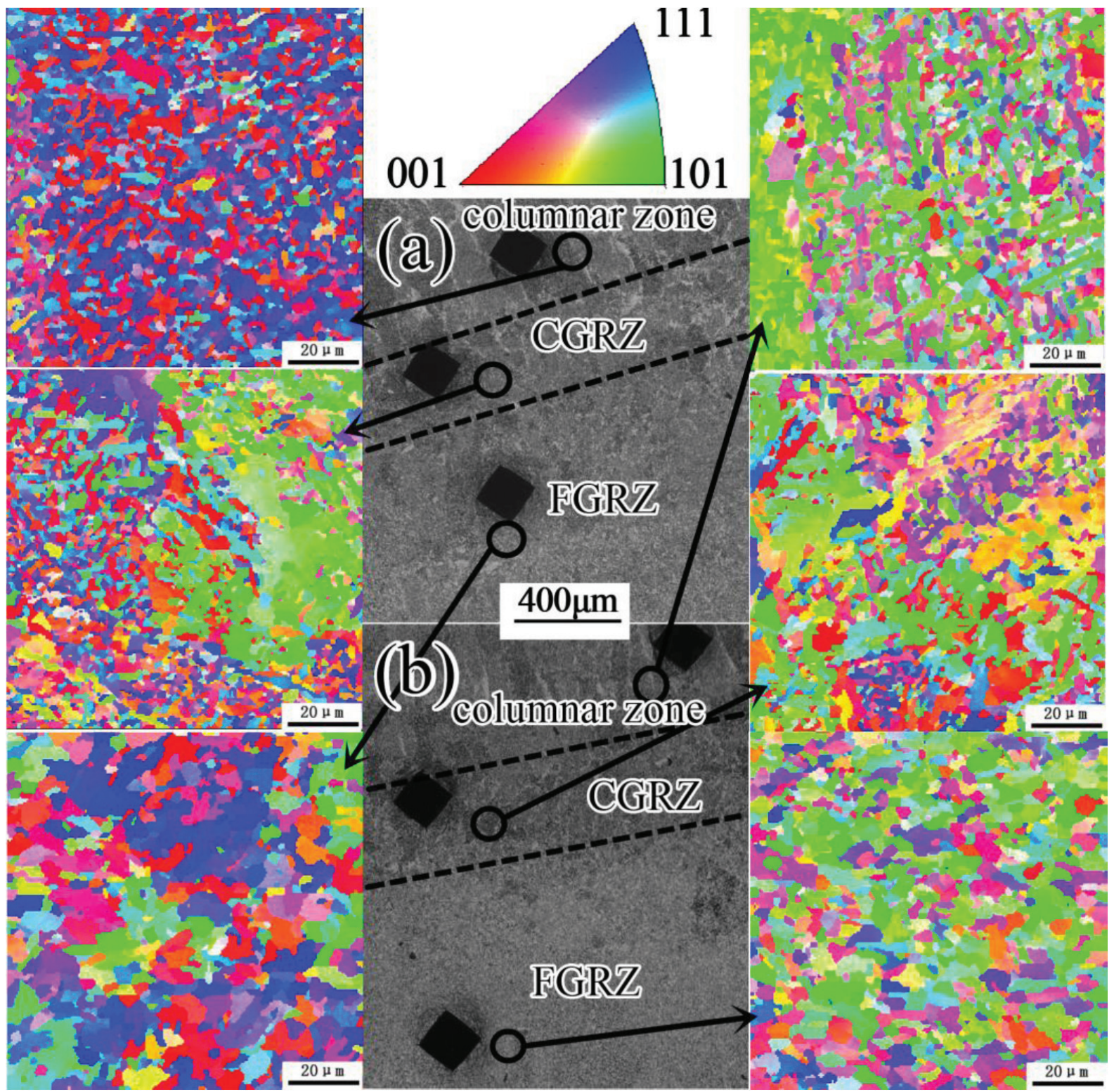

Figure 6: EBSD scanning area and the results in the deposited metals: a) No. 1 and b) No. 2

Table 6: Large grain boundaries information of the regional microstructure

\begin{tabular}{|c|c|c|c|c|c|c|}
\hline & \multicolumn{2}{|c|}{ Columnar zone } & \multicolumn{2}{c|}{ CGRZ } & \multicolumn{2}{c|}{ FGRZ } \\
\hline & $15^{\circ}-50^{\circ}$ & $>50^{\circ}$ & $15^{\circ}-50^{\circ}$ & $>50^{\circ}$ & $15^{\circ}-50^{\circ}$ & $>50^{\circ}$ \\
\hline No.1 & $8 \%$ & $37 \%$ & $11 \%$ & $39 \%$ & $31 \%$ & $28 \%$ \\
\hline No. 2 & $12 \%$ & $42 \%$ & $12 \%$ & $38 \%$ & $21 \%$ & $24 \%$ \\
\hline
\end{tabular}

The typical CGRZ microstructure is presented in Figure 5. With respect to the microstructure, GBF was distributed in the grain boundary of the CGRZ, whereas AF was distributed in the grain. Granular bainite (GB) was observed in the No. 2 specimen of CGRZ. Because of the fact that CGRZ contained the GBF, GB, and M-A constituents, it can be considered to exhibit local brittle zones of deposited metals. In fact, the actual impact denoted one or more brittle reheated zones. ${ }^{21}$ The EBSD

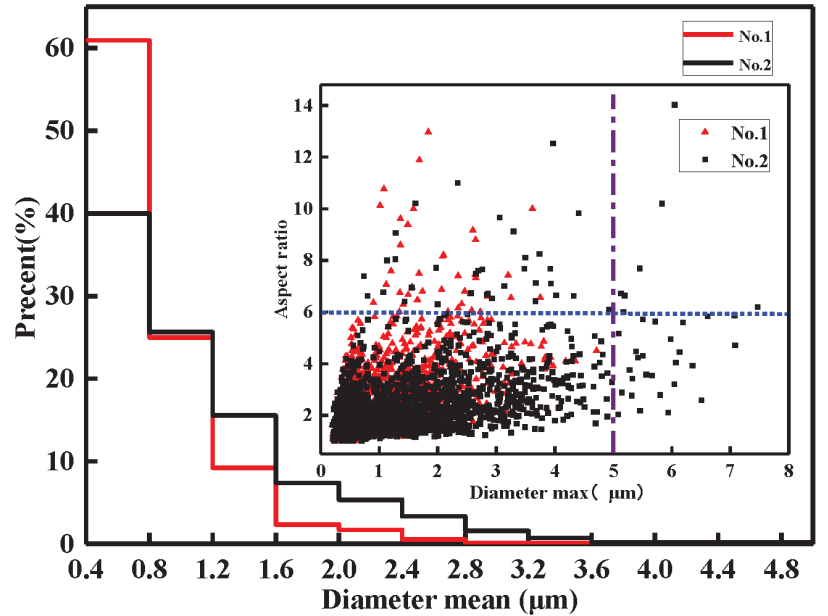

Figure 7: Distribution of the M-A constituent mean size with respect to the maximum size and aspect ratio 
analysis results denoted that the crystallographic parameters of AF in the CGRZ were approximate, indicating that the AF in the CGRZ of the two groups of specimens were similar in terms of shape and growth capacity. The deposited metals underwent rapid heating and cooling, and the whole thermal cycle time was short. Recrystallization occurred in part of the CGRZ microstructure, and a new solid phase transition could be observed in the austenite before the carbide dissolved into the austenite. Hence, reasonable welding parameters and procedures are expected to be adopted to avoid CGRZ deterioration. $^{21}$

The columnar crystals disappeared after reheating, which could be the reason why the multilayer and multipass welding process improved the mechanical properties of the weld microstructure. The main microstructure of the FGRZ is fine blocky ferrite. The microstructural details of FGRZ obtained by EBSD are presented in Table 5. Grain boundaries of less than $15^{\circ}$ are usually defined as low-angle grain boundaries. The No. 1 FGRZ contained $59 \%$ large-grain boundaries, much more than that contained in No. 2 FGRZ. This can be attributed to the fact that the No. 1 specimen retained more grain boundary in $15-50^{\circ}$. In addition, the No. 1 specimen retained a $15-50^{\circ}$ range of grain boundary in FGRZ to ensure that the large-angle grain boundary ratio increased; further, the process of crack propagation became more complex, increasing the crack-propagation-absorbed energy. As the Mn content changes, the proportion of the large-angle microstructure grain boundary increases with low Mn content, whereas the proportion of the large-angle microstructure grain boundary decreases with high Mn content.

Table 7 presents the quantitative analysis results of the M-A constituents. As can be observed, the mean equivalent diameter of the M-A constituents of the No. 2 specimen was $1.15 \mu \mathrm{m}$, significantly larger than the average diameter of the No. 1 specimen. Further, the M-A constituent content of the two groups was similar. The distribution of each size range is presented in Figure 7. When compared with the No. 1 specimen, the proportion of large-sized M-A constituents in the No. 2 specimen was significantly increased. The diameter statistics results imply that an increase in Mn leads to obvious coarsening of the $\mathrm{M}-\mathrm{A}$ constituents. The measurement results of the distribution of the $\mathrm{M}-\mathrm{A}$ constituent maximum size and aspect ratio are presented in Figure 7. The maximum size of the $\mathrm{M}-\mathrm{A}$ constituents in the No. 1 specimen was lower than $5 \mu \mathrm{m}$, whereas that in the No. 2 specimen was more than $7 \mu \mathrm{m}$ with no significant change in the aspect ratio.

Table 7: Results of the M-A constituent quantification

\begin{tabular}{|c|c|c|}
\hline & $\begin{array}{c}\text { Volume fractions } \\
(\%)\end{array}$ & $\begin{array}{c}\text { Mean equivalent } \\
\text { diameter }(\mu \mathrm{m})\end{array}$ \\
\hline No. 1 & 3.42 & 0.79 \\
\hline No. 2 & 3.14 & 1.15 \\
\hline
\end{tabular}

According to Griffith's theory, an increase in the maximum chord length size facilitates easy crack nucleation, negatively influencing the impact toughness. The increase in Mn content stabilized the austenite and coarsened the M-A components, promoting the nucleation of cracks.

All the results indicate that the microstructures of the WS-deposited metals in the case of multilayer and multipass welding are extremely complicated. Columnar crystallization was refined with increasing Mn content; however, FSP precipitated at the grain boundary. In fact, the deposited metals exhibit optimal impact toughness because they exhibit suitable percentages of GBF and FSP. ${ }^{22,23}$ At this time, the columnar crystals comprise AF, which is usually very fine and can easily result in a large-angle grain boundary. The view that a large-angle grain boundary is favorable for ensuring suitable impact toughness in the crack-propagation process has been extensively accepted. The smaller the effective grain size of block ferrite in the FGRZ, the better will be the impact toughness. In the process of multilayer and multipass welding, the selection of appropriate welding parameters can enlarge the fine-grain reheating area and reduce the size of the brittle reheated zones.

The impact-toughness properties are determined by the microstructures. Therefore, maintaining a satisfactory combination of strength and toughness requires a comprehensive consideration of the chemical composition of the deposited metals.

\section{CONCLUSIONS}

In this study, a new welding consumable was developed with considerable corrosion resistance and impact toughness. The following conclusions can be obtained from an in-depth analysis of the weathering deposited metals in the case of multipass welding:

- the Mn content fluctuations did not significantly influence the self-corrosion potential of the deposited metals. This rule can be used to design the mechanical properties of the WS-welding consumables after the corrosion-resistance property was satisfied;

- the impact toughnesses corresponding to $1.05 \% \mathrm{Mn}$ were generally larger than those of $1.34 \% \mathrm{Mn}$. The deposited metals with $1.05 w / \%$ Mn when compared with those in the case of 1.34 w/\% increased the impact toughness by $40 \%$; further, the increment in crack-propagation-absorbed energy accounted for 88 $\%$ of the increment in impact energy;

- a reasonable Mn content can reduce the proportion of brittle phases (FSP and GBF) in the columnar zone of the deposited metals, cause the reheated fine-grain area to exhibit a considerable amount of large-grain boundary, and refine the $\mathrm{M}-\mathrm{A}$ constituents. Therefore, it was considered to be difficult to initiate and propagate the cracks. 


\section{Acknowledgment}

This work was supported by the National Key R\&D Program of China (NO.2017YFB304800 and NO.2017YFB304804).

\section{REFERENCES}

${ }^{1}$ M. Morcillo, I. Díaz, B. Chico, H. Cano, D. de la Fuente, Weathering steels: from empirical development to scientific design. A review, Corrosion Science, 83 (2014), 6-31 doi:10.1016/j.corsci.2014.03.006

${ }^{2}$ V. Křivý, V. Urban, M. Kubzová, Thickness of Corrosion Layers on Typical Surfaces of Weathering Steel Bridges, Procedia Engineering, 142 (2016), 56-62, doi:10.1016/j.proeng.2016.02.013

${ }^{3}$ J. Guo, C. J. Shang, S. W. Yang, H. Guo, X. M. Wang, X. L. He, Weather resistance of low carbon high performance bridge steel, Materials \& Design, 30 (2009), 129-134, doi:10.1016/j.matdes. 2008.04.038

${ }^{4}$ Q. Yu, C. F. Dong, Y. H. Fang, K. Xiao, C. Y. Guo, G. He, X. G. Li, Atmospheric Corrosion of Q235 Carbon Steel and Q450 Weathering Steel in Turpan, China, Journal of Iron \& Steel Research International, 23 (2016) 10, 1061-1070, doi:10.1016/S1006-706X (16)30158-3

${ }^{5}$ V. Křivý, P. Konečný, Real material properties of weathering steels used in bridge structures, Procedia Engineering, 57 (2013), 624-633, org:10.1016/j.proeng.2013.04.079

${ }^{6}$ J. Cheng, J. Qing, Y. Guo, H. Shen, High-strength weathering steels obtained using bainite matrix and nanoscale co-precipitation, Materials, 236 (2019) 307-311, doi:10.1016/j.matlet.2018.10.076

${ }^{7}$ X. L. Wang, Y. R. Nan, Z. J. Xie, Y. T. Tsai, J. R. Yang, C. J. Shang, Influence of welding pass on microstructure and toughness in the reheated zone of multi-pass weld metal of 550, MPa offshore engineering steel, Materials Science and Engineering: A, 702 (2017) 196-205, doi:10.1016/j.msea.2017.06.081

${ }^{8}$ M. H. Avazkonandeh-Gharavol, M. Haddad-Sabzevar, A. Haerian, Effect of chromium content on the microstructure and mechanical properties of multipass MMA, low alloy steel weld metal, Journal of Materials Science, 44 (2009), 186-197, doi:10.1007/s10853-0083103-2

${ }^{9}$ X. Xiao, Y. Peng, C. Ma, Z. Tian J, Effects of Alloy Element and Microstructure on Corrosion Resistant Property of Deposited Metals of Weathering Steel, Journal of Iron and Steel Research, International, 23 (2016), 171-177, doi:10.1016/S1006-706X(16) 30030-9

${ }^{10}$ V. Urban, V. Krivy, K. Kreislova, The Development of Corrosion Processes on Weathering Steel Bridges, Procedia Engineering, 114 (2015), 546-554, doi:10.1016/j.proeng.2015.08.104
${ }^{11}$ S. Hara, T. Kamimura, H. Miyuki, M. Yamashita, Taxonomy for protective ability of rust layer using its composition formed on weathering steel bridge, Corrosion Science, 49 (2007), 1131-1142, doi:10.1016/j.corsci.2006.06.016

${ }^{12}$ C. Zhang, D. Cai, B. Liao, T. Zhao, Y. Fan, A study on the dual-phase treatment of weathering steel, Materials Letters, 58 (2004) 1524-1529, doi:10.1016/j.matlet.2003.10.018

${ }^{13}$ X. Luo, X. Chen, T. Wang, S. Pan, Z. Wang, Effect of morphologies of martensite-austenite constituents on impact toughness in intercritically reheated coarse-grained heat-affected zone of HSLA steel, Materials Science and Engineering: A, 710 (2018), 192-199, doi:10.1016/j.msea.2017.10.079.

${ }^{14}$ I. Kim, H. Nam, M. Lee, D. Nam, Y. Park, N. Kang, Effect of Martensite-Austenite Constituent on Low-Temperature Toughness in YS $500 \mathrm{MPa}$ Grade Steel Welds, Metals, 8 (8), 638, doi:10.3390/ met8080638

${ }^{15}$ C. Zhang, S. Yang, B. Gong, C. Deng, D. Wang, Effects of post weld heat treatment (PWHT) on mechanical properties of C-Mn weld metal: Experimental observation and microstructure-based simulation, Materials Science and Engineering: A, 712 (2018), 430-439, doi:10.1016/j.msea.2017.12.006

${ }^{16}$ H. K. D. H. Bhadeshia (Eds.), Bainite in Steels (second edition), Cambridge University Press, London, 2001, 237-276

${ }^{17}$ W. Zhang, welding metallurgy, China Machine Press, Tianjin, 2004, $150-153$

${ }^{18}$ Y. Shao, C. Liu, Z. Yan, H. Li, Y. Liu, J. Mater., Formation mechanism and control methods of acicular ferrite in HSLA steels: A review, Journal of Materials Science \& Technology, 34 (2018), 737-744, doi:10.1016/j.jmst.2017.11.020.

${ }^{19}$ J. H. Shim, Y. W. Cha, S. H. Chung, J. D. Shim, D. N. Lee, Nucleation of Intragranular Ferrite at Ti2O3 Particle in Low Carbon Steel, Acta Materialia, 47 (1999) 9, 2751-2760, doi:10.1016/S1359-6454 (99)00114-7

${ }^{20}$ Y. Kang, K. Han, J. H. Park, C. Lee, Variation in the chemical driving force for intragranular nucleation in the multi-pass weld metal of Ti-containing high-strength low-alloy steel, Metallurgical and Materials Transactions A, 46 (2015), 3581-3591, doi:10.1007/ s11661-015-2958-5

${ }^{21}$ B. Beidokhti, A. H. Koukabi, A. Dolati, Influences of titanium and manganese on high strength low alloy SAW weld metal properties, Materials Characterization, 60 (2009), 225-233, doi:10.1016/ j.matchar.2008.09.005

${ }^{22}$ Y. T. Shin, H. W. Lee, Evaluation of fracture behavior of the reheated weld zone in API 2W Gr. 50 steel weld metals, Metals and Materials, 18 (2012), 863-867, doi:10.1007/s12540-012-5018-3

${ }^{23}$ J. M. Gregg, H. K. D. H. Bhadeshia, Solid-state nucleation of acicular ferrite on minerals added to molten steel, Acta Materialia, 45 (1997), 739-748, doi:10.1016/s1359-6454(96)00187-5 